\title{
Polymers for Combating Biocorrosion
}

\begin{abstract}
Jing Guo', Shaojun Yuan ${ }^{2 *}$, Wei Jiang², Li Lv², Bin Liang² and Simo O. Pehkonen
${ }^{1}$ Research Institute of Petroleum Engineering and Technology, Northwest Oilfield Company, Sinopec, Urumqi City, China ${ }^{2}$ College of Chemical Engineering, Sichuan University, Chengdu, China, ${ }^{3}$ Department of Environmental and Biosciences, University of Eastern Finland, Kuopio, Finland
\end{abstract}

Biocorrosion has been considered as big trouble in many industries and marine environments due to causing of great economic loss. The main disadvantages of present approaches to prevent corrosion include being limited by environmental factors, being expensive, inapplicable to field, and sometimes inefficient. Studies show that polymer coatings with anticorrosion and antimicrobial properties have been widely accepted as a novel and effective approach to prevent biocorrosion. The main purpose of this review is to summarize up the progressive status of polymer coatings used for combating microbial corrosion. Polymers used to synthesize protective coatings are generally divided into three categories: (i) traditional polymers incorporated with biocides, (ii) antibacterial polymers containing quaternary ammonium compounds, and (iii) conductive polymers. The strategies to synthesize polymer coatings resort mainly to grafting antibacterial polymers from the metal substrate surface using novel surface-functionalization approaches, such as free radical polymerization, chemically oxidative polymerization, and surface-initiated atom transfer radical polymerization, as opposed to the traditional approaches of dip coating or spin coating.

Keywords: biocorrosion, polymeric coatings, biocides, quaternary ammonium compounds, conductive polymers, antibacterial

\section{INTRODUCTION}

The activities of microbial organisms have led to the acceleration in corrosion rate of metals, such as the stimulation of microorganisms to cathodic or anodic reactions or the establishment of differential oxygen concentration cells in localized electrolytic environment by microorganisms, is generally defined as biocorrosion, or microbially-induced corrosion (MIC) (Hamilton, 1985; Videla, 1996; Beech and Sunner, 2004). Biocorrosion has been widely recognized as a serious problem in many industries, oil fields and marine environments. The economical loss directly associated with biocorrosion has been estimated to be at least $20 \%$ of corrosion with a direct cost of 30-50 billion dollars per year worldwide (Heitz et al., 1996; Javaherdashti, 1999). The biocorrosion prevention of structural materials has, therefore, attracted considerable interests of researchers in corrosion field over past decades. Different strategies, such as biocides, cathodic protection, beneficial bacterial biofilms, and protective coatings, have been proposed to combat biocorrosion (Videla, 2002; Videla et al., 2004; Little et al., 2007; Zuo, 2007).

The conventional approach to address inhibiting/mitigating biocorrosion is to use oxidizing biocides, such as chlorine, bromine, ozone, or non-oxidizing biocides, such as formaldehyde, glutaradehyde, quaternary ammonium compounds, isothiazolines in reducing different types of organisms in an aqueous system (Videla and Herrera, 2005). Although biocide injection has been 
extensively employed in preventing biofouling and biocorrosion in steel pipes (Franklin et al., 1991) or a closed system (Gardner and Stewart, 2002), the treatment outcome is found to be far from satisfactory. This result is caused by the fact that biocorrosion usually takes place underneath the biofilms (Costerton, 1987) and sessile organisms within biofilms are found more resistant to biocides than those in a planktonic population (Viera et al., 1999). It has been reported that biofilms dramatically enhanced resistance to antimicrobial agents (Donlan and Costerton, 2002; Dunne, 2002). Meanwhile, the long-term usage of a single biocide inevitably results in more resistance of microorganisms growing inside the biofilm (Cheung and Beech, 1996). This in turn requires higher concentrations of biocides to make up the increased resistance against biocides. In some cases, high biocide concentrations can result in the initiation and propagation of localized corrosion (Franklin et al., 1991; Neville et al., 1998). Furthermore, biocide treatment may pose a negative impact on environment due to their inherent toxicity (Guiamet and Gómez de Saravia, 2005), and it may also inactivate the activity of nontargeted organisms. Cathodic protection has been reported to effectively decelerate corrosion of stainless steel induced by aerobic bacteria (Guezennec, 1994), while it shows no effect on the activity of anaerobic bacteria, such as sulfate-reducing bacteria (SRB). Thus, the prevention of the initiation of localized corrosion by SRB appears to be very difficult. In addition, the costs of biocide treatment and cathodic protection techniques are very high for many industries and the closed systems.

An environmentally benign strategy of using beneficial bacterial biofilms to control biocorrosion has been developed in recent years to replace the usage of biocides. Corrosion inhibition derived from biofilms has been reported for carbon steel (Pedersen and Hermansson, 1989, 1991; Hernandez et al., 1994; Jayaraman et al., 1997, 1999a; Dubiel et al., 2002), stainless steel (Jayaraman et al., 1999a; Dubiel et al., 2002), aluminum (Jayaraman et al., 1999b; Örnek et al., 2002; Zuo et al., 2005), and copper (Jayaraman et al., 1999b). The possible mechanisms involve: (i) the formation of biofilms acting as a diffusion barrier to impede metal dissolution (Pedersen and Hermansson, 1989, 1991; Hernandez et al., 1994), (ii) corrosive agents such as oxygen being removed by aerobic respiration microorganisms (Jayaraman et al., 1997, 1999b; Dubiel et al., 2002), (iii) growth inhibition of corrosion-causing bacteria such as SRB by antimicrobials generated within biofilms (Jayaraman et al., 1999a,c; Zuo et al., 2004), (iv) generation of protective layers (e.g., $\gamma$-polyglutamate) by biofilms (Örnek et al., 2002). Although extensive laboratory studies indicate various possibilities of control corrosion using bacteria for a number of metallic alloys, the application of this approach has not been totally successful. There are some potential problems that need to be further addressed and elucidated prior to being applied in the field. First, the fundamental assumption in most of the published research on biofilm inhibition lies in the fact that the formation of biofilms can be controlled and predicted. As a matter of fact, it is difficult to predict the formation of with certainty, because even a very small perturbation in the environments, such as temperature, nutrient concentration, $\mathrm{pH}$, and flow, has a significant effect on the biofilm composition. Second, the role of biofilms in corrosion inhibition is still controversial, because the same organisms reported causing biocorrosion are yet reported to inhibit biocorrosion. For examples, Pseudomonas sp. S9 and Serratia marcescens EF 190 were found to accelerate corrosion of iron and nickel relative to sterile conditions by Pedersen et al. (1988), while the same researchers also reported the corrosion inhibition of the above two strains for carbon steel (Pedersen and Hermansson, 1989, 1991). It has been reported that extracellular materials bind metal ions for interpreting as the mechanism for both biocorrosion (Beveridge and Doyle, 1989) and corrosion inhibition (Houghton et al., 1988). Third, the results of field studies using biofilms inhibition are less than satisfactory compared to those of laboratory studies (Arps et al., 2003).

By providing a barrier between environments and various substrates, protective coatings are the most common solutions adapted by many industries against corrosion. This is indicated by the fact that most of the cost of corrosion prevention (about $89.5 \%$ of total costs) is ascribed to the usage of protective coatings (Koch et al., 2002). Thereby, protective coatings have been considered as a major approach to protect substrates from biocorrosion ever since the 1980s, when the damage due to biocorrosion began to be widely recognized, especially where biocides is restricted from application (such as open systems). Protective coatings are usually divided into inorganic coatings (such as galvanizing and metalizing) and organic coatings (such as silicone, epoxy resins, fluorinated compounds, and all polymeric coatings) (Videla, 1996, 2002). Ilhan-Sungur et al. (2007) and Ilhan-Sungur and Cotuk (2010) reported that the galvanized steel was corroded by SRB within the heterogeneous biofilm upon a long immersion period in a recirculating cooling tower system. The inorganic zinc coatings were also found to suffer from biocorrosion by SRB (Muntasser et al., 2002). Despite of being corrosion resistant to the attack by microorganisms, titanium oxide coatings were susceptible to bacterial adhesion and biofilm formation (Yuan et al., 2008). Organic coatings are frequently referred to as the polymer coatings. Owing to their good barrier ability and their high corrosion resistance, polymer coatings have been extensively employed as a good method of protection against biocorrosion (Mansfeld et al., 1997, 1998; Little et al., 1999; Al-Darbi et al., 2002; Mazumder et al., 2003). Based on practical experience, the effectiveness of polymer coatings in combating biocorrosion is associated with the following problems: (i) the crack, defect, or crevice of polymer coatings are favorable for the occurrence of localized corrosion. Previous studies have demonstrated preferential colonization on a heterogeneous surface, such as scratches, cracks, and pinholes (Characklis and Marshall, 1990; Wagner et al., 1996), (ii) a good bond between polymer coatings and the substrate surface is significant to their stability and durability. Moisture beneath a poorly bonded coating may contain microbial contaminants, and conditions are favorable for anaerobic growth (Videla, 1996), (iii) polymer coatings readily suffer from microbiologically induced degradation, since some microorganisms can use the coating films as a nutrient source by their physiological activities on the coating surface, thus resulting in the loss of protection capacity of coatings. Furthermore, the corrosive biodegradation 
products have been found detrimental to the biofilm-attached metals (Flemming, 1998; Kopteva et al., 2004). To circumvent the problem of microbial degradation, the biocidal functionality has been conferred to the polymer coatings to inhibit the attachment of bacterial cells and subsequent formation in recent years (Crum et al., 1967; Sugama, 1995; Sugama and DuVall, 1996; Thomas et al., 2004; Ananda Kumar et al., 2006; Choi et al., 2007; Yuan et al., 2007, 2009a,b,c, 2010a; Lebrini et al., 2008; Stobie et al., 2009; Videla and Herrera, 2009; Wan et al., 2009; Zafar et al., 2009; Yang et al., 2014; Grover et al., 2016; Yesudass et al., 2017).

Within the past few years, the techniques to fabricate uniform, robustly bonded and antibacterial polymer coatings on metallic substrates have been developed (Videla and Herrera, 2009; Wan et al., 2009; Yuan et al., 2009a,b,c, 2010a; Yang et al., 2014), and ever more studies demonstrate the protective functionality of polymer coatings against biocorrosion. There is a recent trend toward increasing the use of polymers with antibacterial and anticorrosive properties in preparation of polymer coatings against biocorrosion. Although there are several reviews regarding biocorrosion control and prevention using biocides or beneficial bacterial biofilms (Jones-Meehan et al., 1992; Videla, 2002; Guiamet and Gómez de Saravia, 2005; Little et al., 2007; Zuo, 2007), few reviews have been published to discuss progress in the area of biocorrosion protection using polymers (or polymer coatings). Accordingly, the aim of the current review is to summarize the protective capacity of different types of polymer coatings to combat biocorrosion. Polymers commonly used for preventing and controlling biocorrosion mainly consists of the following three categories: (i) traditional polymers incorporated with biocides, (ii) antibacterial polymers containing quaternary ammonium compounds, and (iii) conductive polymers.

\section{TRADITIONAL POLYMERS INCORPORATED WITH BIOCIDES FOR BIOCORROSION PROTECTION}

Traditional polymers being utilized to protect metal substrates from biocorrosion damage are mainly composed of polyurethane, fluorinated compounds, epoxy resins, polyimides, silicone, coal-tar epoxy, and polyvinyl chloride. Videla (2002) demonstrated the good performance of coal-tar epoxy and epoxy resin coatings to combat biocorrosion, while PVC-based coatings exhibited poor protection performance against corrosion induced by microorganisms. Mansfeld et al. (1997, 1998) and Little et al. (1999) systematically studied the protection performance of different polymer coating systems, such a slow VOC alkyd, silicone alkyd, polyurethane, latex, and epoxy polyamide used as mid-coat and top-coat of polymer coatings, respectively, on steel species being exposed in natural and synthetic seawater. They concluded that the coating degradation by microorganisms can be observed for all the polymer coatings systems except for polyamide-epoxy coating system. Moreover, the effectiveness of corrosion protection decreases in the sequence of polyamide-epoxy, polyurethane, latex, and alkyd (Mansfeld et al., 1997, 1998). Little et al. (1999) investigated the effect of marine bacteria on localized corrosion for polymer-coated steels, of which, six polymer coating systems with epoxy polyamide and polyurethane as mid-coat and top-coat were chosen. Their experimental results demonstrated that the distribution of bacteria was independent of the coating combinations, and the bacteria were found to adhere preferentially on the iron corrosion products in coating defects, thus leading to localized corrosion underneath the polymer coatings (Al-Darbi et al., 2002). Jones-Meehan et al. (1992) and Miller et al. (1964) used energy dispersive X-ray spectroscopy (EDS) to investigate the change of polymercoated steel exposed to mixed communities of marine bacteria. The breaching of epoxy, nylon, and polyurethane coatings on the surface of steel coupons were detected by the EDS spectra. They also demonstrated the colony formation of a diverse assemblage of bacteria on all the polymer-coated surface of steel coupons. Thereby, Videla $(1996,2002)$ concluded two prerequisites for polymer coatings against biocorrosion: (i) no alternation of polymer coatings by the bacterial attack and no release of corrosive products during degradation, (ii) polymer coatings decrease the risk of MIC by reducing bacterial adhesion and inhibiting biofilm formation. Currently, traditional polymer coatings are frequently furnished with antibacterial functionality by biocide incorporation to inhibit biofilm formation, and thereby minimizing their microbial degradation.

Polyurethanes have been extensively used against biocorrosion since the 1970s, due to their impermeability, good adhesion and abrasion resistance, flexibility, and biocompatibility (Crum et al., 1967; Seal and Pathirana, 1982; Bentham et al., 1987; Kennedy, 2002). However, polyurethanes have been known to be degraded by microorganisms (Kay et al., 1993; Gu et al., 1998a; Ramezanzadeh et al., 2015). When used as insulation coatings for corrosion, the microbial degradation effect on polyurethane coatings could cause substantial damage, and thus leading to a loss in corrosion resistance. Several investigators have attempted to impregnate antibacterial agents into the matrix of polyurethane coatings to minimize the microbial degradation effect (Stobie et al., 2009; Grover et al., 2016; Yesudass et al., 2017). For example, it was reported that about $0.1-5 \%$ of non-toxic antibacterial agents was chemically (rather than physically) incorporated into the polyurethane resins, and thus the antibacterial agents become an integral and permanent part of the molecular structure across the entire polyurethane coating film (Grover et al., 2016). The polyurethane coatings incorporated with antibacterial agents showed a significant percentage ( $>99 \%$ ) of reduction of microorganisms, and their antibacterial activity remained unchanged over time due to non-occurrence of volatilizing and leaching of the antibacterial agents. Alternatively, Stobie et al. (2009) reported that the perfluoropolyether-urethane coatings can be imparted with a bactericidal ability by doping them with silver ions, and that silver ions released from the fluorinated polyurethane coatings exhibited good antibacterial activity against microorganisms. It is worthwhile to point out that the polyurethane polymer coatings were mainly prepared by dip coating or spin coating approaches. The adhesion between the coatings and substrate surface and the stability of the coatings are of great 
concern over a long-term exposure period. Ramezanzadeh et al. reported to modify the surfaces of graphene oxide (GO) nanosheets by grafting of polyisocyanate (PI) chains (Tiwari and Hihara, 2010). Success in grafting of PI chains onto GO nanosheets via amides and carbamate esters bonds was ascertained by X-ray photoelectron spectroscopy (XPS), and X-ray diffraction and thermal gravimetric analyses. Salt spray tests and electrochemical study demonstrated that incorporation of 0.1 weight $\%$ of PI-modified GO nanosheets into the polyurethane matrix could significantly improve the anticorrosion properties and ionic resistance of polymer coatings (Tiwari and Hihara, 2010).

Silicones are composed of a variety of organic-inorganic hybrid materials, which have been widely considered as alternative to replace chromate ion coatings for corrosion inhibition (Brady, 1999). Due to their low elastic modulus resulting from a flexible, inorganic -Si-O backbone linkage and a critical surface tension as derived from the alkyl side chains, silicones have been extensively employed as fouling-release coatings (Edwards et al., 1994; Nevell et al., 1996; Watermann et al., 1997; Brady and Singer, 2000; Estarlich et al., 2000; Kus et al., 2005). Moreover, silicones have also been reported to possess a good corrosion protection ability (Gu et al., 1998b). Silicones consist mainly of polydimethylsiloxane (PDMS) and its derivatives for fouling-release and corrosion-resistant coatings. However, silicone rubbers have been reported to be susceptible to deterioration by microorganisms (Barriosa et al., 2005; Ramezanzadeh et al., 2015). A practical example is biocorrosion of medicalgrade silicone rubber (Flemming, 1998). Thus, antifoulants or biocides have been entrapped in the poly(siloxane) matrices via blending (Haque et al., 2005; Ye et al., 2008) or covalent bonding (Sugama and Cook, 2000; Thomas et al., 2004) to produce antifouling coatings. Haque et al. (2005) incorporated sodium benzoate into silicone coatings and found that the resulting coatings have an ability to prevent some bacteria and barnacles from their surfaces. Thomas et al. (2004) and Ye et al. (2008) designed experiments to incorporate the biocide triclosan [5-chloro-2-(2,4-dichloro- phenoxy)phenol, TCS] into silicone coatings via covalent bonds. The synthetic scheme is schematically illustrated in Figure 1. The biocide triclosan was first modified with alkenyl moieties to facilitate hydrosilylation and was then incorporated into the silicone backbone to obtain a biocide-containing resin with residual $\mathrm{Si}-\mathrm{H}$ groups. The vinyl-terminated PDMS was utilized as anchoring sites<smiles>Oc1cc(Cl)ccc1Oc1ccc(Cl)cc1Cl</smiles>

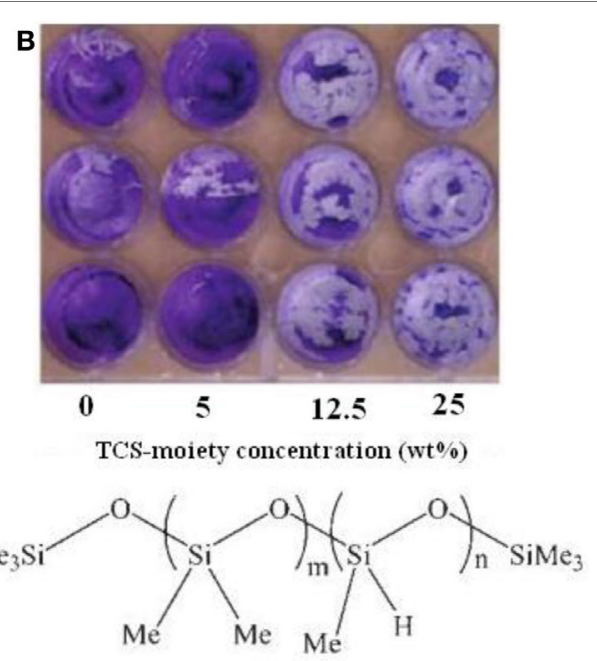<smiles>[R2]Oc1cc(Cl)ccc1Oc1ccc(Cl)cc1Cl</smiles>

Toluene/ Pt catalyst $8 \mathrm{~h} / 90^{\circ} \mathrm{C}$<smiles>CC(C)(O[Si](C)(C)O[Si](C)(C)C(C)(C)O[Si](C)(C)C)[Si](C)(C)O[Si](C)(C)Oc1cc(Cl)ccc1Oc1ccc(Cl)cc1Cl</smiles>

FIGURE 1 | (A) Process of the modification of trisolan biocide and the incorporation of modified biocide intosiloxane, (B) images of C. Iytica biofilm coverage after crystal violet staining on polydimethylsiloxan coatings containing TCS moieties. Reprinted with permission from Ye et al. (2008). Copyright 2008 American Chemical Society. 
to prepare coatings (Figure 1A). As shown in Figure 1B, the silicone coatings containing a 0 and 5 weight $\%$ of TCS moieties exhibited poor antibacterial with complete coverage of the bacterial biofilm, whereas the biofilm surface coverage was greatly reduced for the coating containing 12.5 and 25 weight $\%$ of TCS moieties. These results demonstrated that a high surface concentration of TCS moieties on the PDMS surface could cause a high degree of retraction of the bacterial biofilm (Sugama and Cook, 2000). Since many biocide-bearing silicone coatings are considered hazardous to the environment, great efforts are expended to develop environmentally benign coatings using natural biocides. Sugama and DuVall (1996) synthesized polyorganosiloxane grafted polysaccharide (i.e., potato starch) copolymers through a heat-catalyzed dehydrating condensation reaction at $200^{\circ} \mathrm{C}$ in air, and incorporated $N$-[3-(triethoxysily) propyl]-4,5,-dihydroimidazole, TSPI into the coating matrix as antimicrobial agents. By using electrochemical impedance spectroscopy (EIS) to characterize the corrosion behavior of the bare $\mathrm{Al}$ and polymer-coated Al specimens, they demonstrated that polyorganosiloxane-grafted starch coatings containing antimicrobial TSPI can increase the pore resistance $\left(R_{\mathrm{po}}\right)$ and enhance the resistance to microbial degradation. As shown in Figure 2, the coating films derived from precursor solutions with (PS)/(TSPI) ratios of $90 / 10$ and $85 / 15$ were most effective to prevent the corrosion of $\mathrm{Al}$ substrates, because the pore resistance $R_{\mathrm{po}}$ of the coated $\mathrm{Al}$ specimens increased by more than two orders of magnitude over that of the bare $\mathrm{Al}$ substrates.

Because of the environmental restrictions to the usage of polymer coatings containing biocides, ever more research is focused on natural polymers (such as polysaccharides) or the incorporation of natural biocides into coatings. Sugama and Cook (2000) used natural polysaccharides such as chitosan (CS), which contain $\beta$-(1-4)-linked D-glucosamine (deacetylated unit) and $N$-acetyl-D-glucosamine, to graft and crosslink with

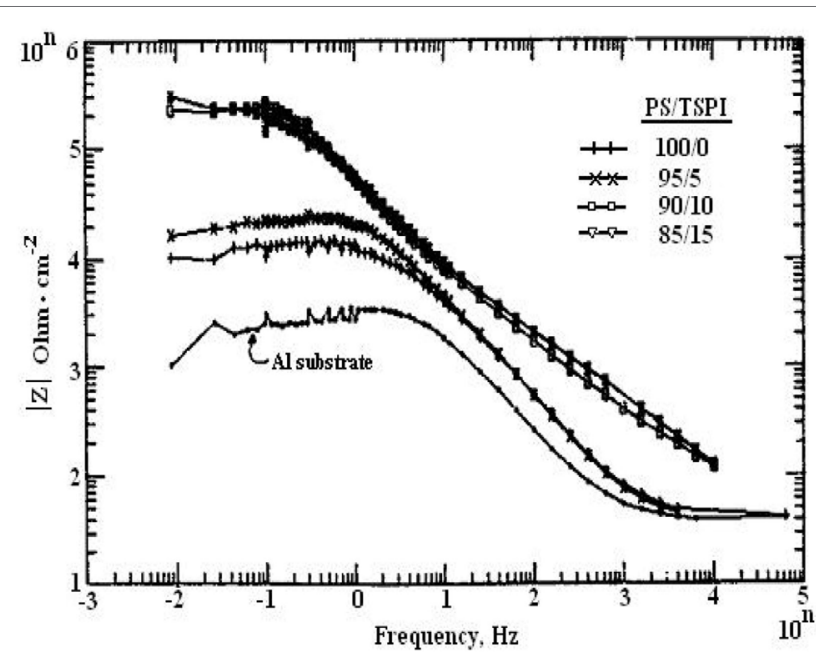

FIGURE 2 | Bode magnitude plots for a bare Al substrates and Al specimens coated with films with 100/0, 95/5, 90/10, and 85/15 ratios. Reprinted with permission from Sugama and DuVall (1996). Copyright 1996 Elsevier Science. poly(itaconic acid) (PIA) via a robust covalent bond derived from a condensation reaction between amino groups $\left(-\mathrm{NH}_{2}\right)$ of the CS and the carboxylic groups $(-\mathrm{COOH})$ of the PIA. The anticorrosion properties of the coating films on the $\mathrm{Al}$ substrates were evaluated by EIS measurements. The PIA-grafted CS polymer coatings were verified to lower ionic conductivity on aluminum, and thus could inhibit corrosive ions from penetrating into the coating pores. Sugama (1995) designed to modify the natural polymer, polygalacturonic acid methyl ester (pectin, PE), by incorporating TSPI into its molecular structure. The TSPImodified PE polymer coating films showed an increase in pore resistance $R_{\mathrm{po}}$ and the marked increase in the microbial degradation resistance. The postulated mechanisms have been interpreted by the decrease in surface hydrophilicity of the coatings and the stabilization of $\mathrm{Al}_{2} \mathrm{O}_{3}$ layers by silanol terminal groups of the coating materials. An alternative approach to prepare environmentally benign coatings is to incorporate natural biocides into the polymer coating matrix. Al-Darbi et al. (2002) comparatively studied the corrosion behavior of pristine mild steel, alkyd-coated mild steel, olive oil-mixed alkyd-coated mild steel, and Menhaden fish oil-mixed alkyd-coated mild steel in the SRB medium. The experimental results showed that bacteria and biofilm were extensively attached to the pristine and alkyd-coated mild steel surface as small clusters or bacterial colonies rather than continuous biofilms, thus resulting in the accelerated corrosion rate of localized corrosion, while an evident inhibition of bacterial adhesion was observed on the surface-modified mild steel with natural additives (olive oil and fish oil)-mixed alkyd coatings. They further demonstrated that mixed natural products (mainly fish oils) combined with oil-based coatings had a significant effect on inhibiting bacterial adhesion and the occurrence of biocorrosion of mild steel.

\section{BIOCORROSION INHIBITION USING ANTIBACTERIAL POLYMERS CONTAINING QUATERNARY AMMONIUM MOIETIES}

As a broad category of cationic compounds, quaternary ammonium compounds (QUATS) have been extensively utilized as biocides and corrosion inhibitors, for example, being used as inhibitors against acid corrosion of iron and steel (Frignani et al., 1991; Tiller et al., 2002; Qi et al., 2017). The synergistic effect between the positive QUATS ions and halide anions usually results in an evident increasing in inhibition efficiency (Frignani et al., 1991; Qi et al., 2017). This is attributed to the cohesive Van der Waals' force between the positive head group/halide ion complex and the positively charged metal surface (Frignani et al., 1991; Tiller et al., 2002; Qi et al., 2017). As biocides, the deactivation mechanisms of QUATS on the bacterial cells is as follows, it can attack the plasmic membranes of the cells, and thus resulting in the dissolution of lipids and the release of intracellular materials (Seter et al., 2012). Detergent-like properties of QUATS provide an additional protection against the formation of polysaccharidic materials, which are released during the process of bacteria colonization (Videla, 2002). Because QUATS have a simultaneous 
action on the corrosion inhibition and bacterial adhesion (Negm and Aiad, 2007), they have been used as biocides to control or inhibit biocorrosion by preventing the formation of biofilm on the substrates (Videla et al., 2000; Lebrini et al., 2008; Badawi et al., 2010). QUATS are mainly applicable to closed systems and perform unsatisfactorily in killing sessile microorganisms within biofilms.

To address the problem of biofilm formation, covalent grafting of the QUATS onto the substrate surface via chemical bonds for inactivating the bacteria during their initial attachment has been developed, because the biofilm formation on the substrate surface is the primary step in initiating biocorrosion. Antimicrobial layers have been successfully prepared via covalently immobilized antibacterial polymers containing quaternary ammonium moieties onto various substrates (Fan et al., 2005; Huang et al., 2008; Yuan et al., 2009b). To covalently graft antibacterial polymers, it is necessary to immobilize a uniform monolayer of initiators on the metal substrate surfaces, as shown in Figure 3. The immobilization of initiators on the metallic substrate surfaces is commonly achieved by a direct coupling of chloromethyl-/chlorosulfonylterminated silane (Yuan et al., 2009a,b,c, 2010a; Yang et al., 2014) and bromomethyl-terminated biomimetic catechol (Koplin et al., 2008). Monomers containing tertiary amino groups, such as 2-dimethylaminoethyl methacrylate (DMAEMA) and 4-vinyl pyridine (4VP), have been extensively used in synthesizing antimicrobial polymers via surface graft polymerization (Figure 3) (Fan et al., 2005; Koplin et al., 2008; Yuan et al., 2009a,b,c, 2010a; Yang et al., 2014). As an example of water-soluble polyamine, polyethyleneimine has not only been employed in preparing antimicrobial coatings (Milovic et al., 2005; Huang et al., 2008; Aguirre et al., 2017), but also been used as a corrosion inhibitor to protect steel (Braunecker and Matyjaszewski, 2007; Kugel et al., 2011; Rajasekar and Ting, 2011).

The conventional approaches of grafting antibacterial polymers on the metallic substrates are achieved by either simple coupling reactions or surface-initiated free-radical polymerization (FRP). Yuan et al. (2009a,b) designed a synthetic route to develop a thin quaternized-viologens layer on the silanized metal surface for mitigating biocorrosion. Their experimental results indicated that at the initial stages of exposure, the immobilized QUATS not only exhibited a good bacterial inhibition efficiency but also caused an evidently decreased corrosion rate of 70/30 $\mathrm{Cu}-\mathrm{Ni}$ alloy specimens under the attack of marine aerobic bacteria Pseudomonas NCIMB 2021. However, both the antibacterial and anticorrosion capacities were reduced due to the gradual damage of the thin films by aggressive ions and bacterial attack after a long-term exposure. To further improve the antimicrobial and anticorrosion abilities of the QUATS-containing coatings,

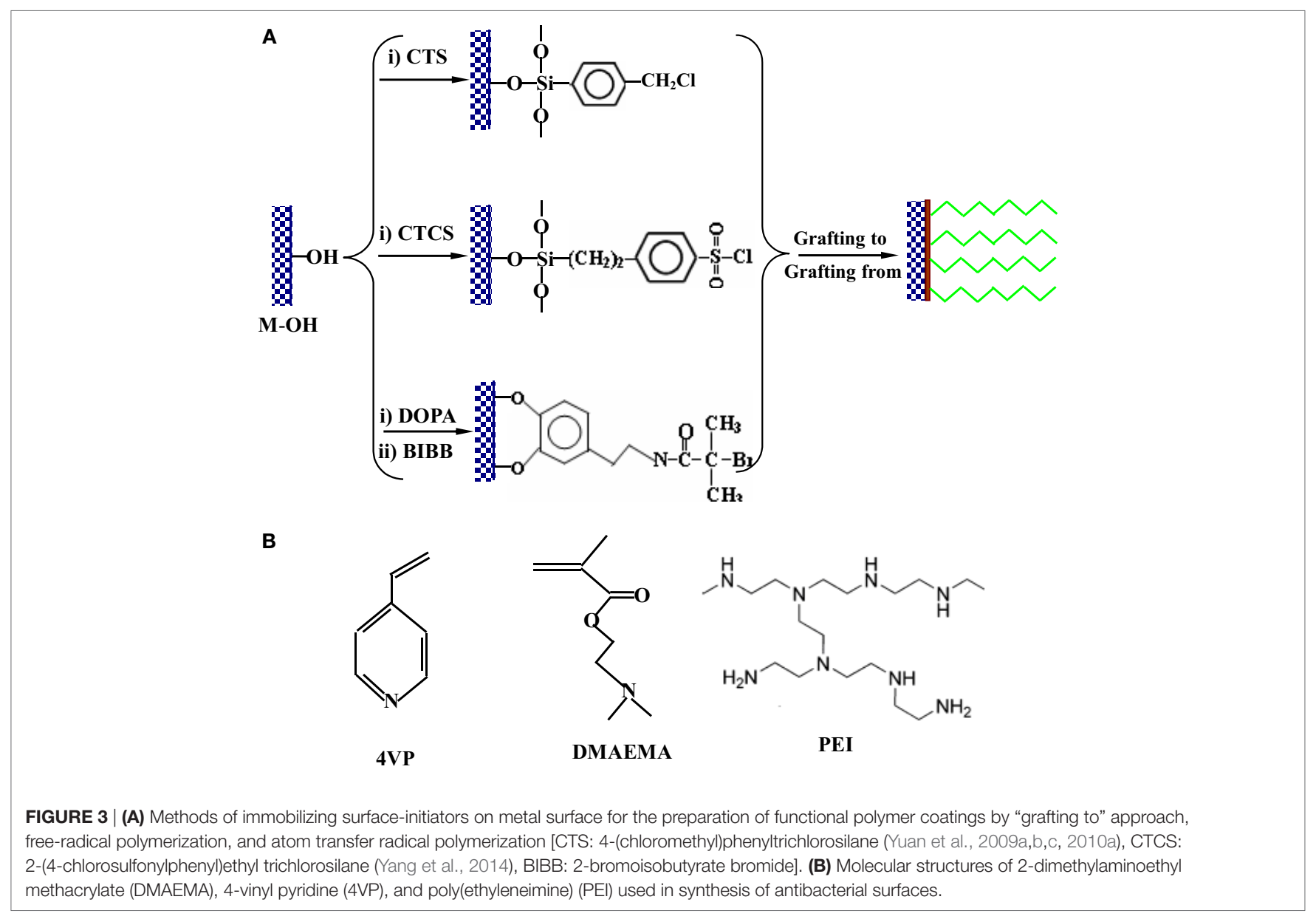


the same research group attempted to develop antimicrobial poly(vinyl- $N$-hexylpyridinium) polymer brushes via surfaceinitiated FRP on the surfaces of 70/30 Cu-Ni alloys (Yuan et al., 2009b). The quaternized P4VP brushes containing abundant pyridinium cation moieties showed a high antibacterial efficiency of 99\% toward Desulfovibrio desulfuricans, and substantially enhanced anticorrosion efficiency to more than $95 \%$ throughout the exposure periods.

Despite of the successful immobilization of antibacterial polymer coatings on metallic substrate surfaces by a conventional "grafting to" approach, including coupling reaction and surfaceinitiated free radical polymerization, these grafting techniques cannot control and precisely design the polymer brushes in a well-defined polydispersity, molecular weight, topography, and surface density of functional groups. The synthesis of tertiary amino group-containing polymers, such as PDMAEMA and P4VP, can be accomplished by graft polymeriztion or copolymerizeation by using atom transfer radical polymerization (ATRP), followed by quaternization to produce antibacterial functionality. Surface-initiated ATRP is a newly developed effective approach to graft functional polymer brushes with a large thickness and a high surface density on solid substrates in a controlled manner (Spinks et al., 2002). Yuan et al. (2009c) first proposed grafting of an antibacterial polymeric brushes on the stainless steel surface to mitigate microbial corrosion induced by SRB. As shown in Figure 4, radical polymerization of DMAEMA monomer containing tertiary amines was performed via surface-initiated ATRP to graft PDMAEMA brushes onto the surfaces of stainless steel with a controlled molecular weight and a low polydispersity. Subsequently, benzyl halide was used to quaternize amino groups of PDMAEMA brushes for conferring the antibacterial functionality on the surfaces of PDMAEMAgrafted SS substrates (Figure 4, Scheme 1). Another strategy to quaternize tertiary amino groups of PDMAEMA brushes was carried out by covalently coupling of viologen with dichloropara-xylene as linker (Figure 4, Scheme 2). The antibacterial assays demonstrated that the viologen-quaternized PDMAEMA brushes, with a substantial increase in the surface-bearing polycation concentration, exhibited higher antibacterial capability to $D$. desulfuricans as compared to the quaternized DMAEMA brushes with benzyl halide, although the latter also exhibited a high antimicrobial capability over D. desulfuricans (Figure 5). Moreover, electrochemical studies of Tafel plots and impedance spectra demonstrated a high anticorrosion behavior of the quaternized PDMAEMA brushes on the steel substrates against biocorrosion by $D$. desulfuricans, as well as noticeable enhancement in corrosion resistance by the coupled viologen layers (Yuan et al., 2009c).

More recently, antibacterial inorganic-organic hybrid coatings were synthesized on the metallic substrate surfaces by a combination of layer-by-layer (LBL) self-assembly and surface-initiated ATRP (Yuan et al., 2010a) or a consecutive surface-initiated ATRP (Yang et al., 2014) to enhance the compactness of the protective coatings and the corrosion resistance to biocorrosion.
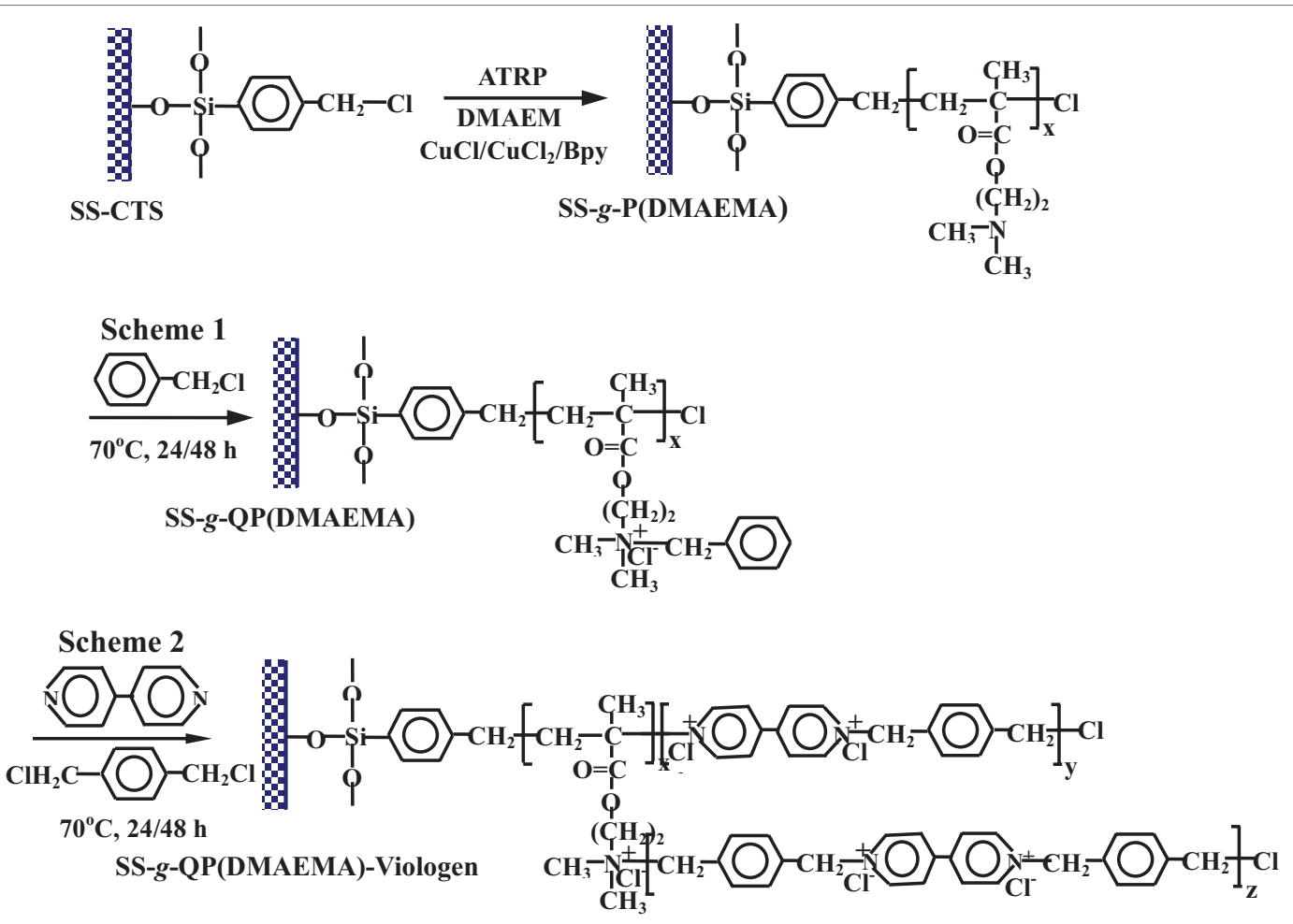

FIGURE 4 | Surface-initiated atom transfer radical polymerization of DMAEMA and subsequent quaterization of PDMAEMA using two different schemesfrom stainless steel surfaces. Reprinted with permission from Yuan et al. (2009c). Copyright 2009 Wiley Periodicals Inc. 
As shown in Figure 6, nanostructured titanium oxide multilayers were first constructed on the steel substrate surface by using LBL self-assembly deposition. A subsequent immobilization of the chloromethyl-terminated sliane on the $\mathrm{TiO}_{2}$-coated steel surface

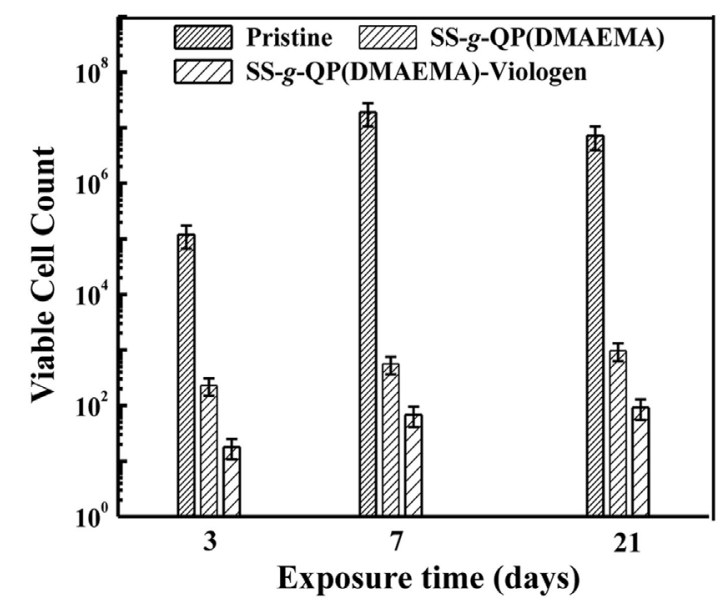

FIGURE 5 | The number of viable Desulfovibrio desulfuricans cells adhered on the pristine, the SS-g-QP (DMAEMA), and the SS-g-QP (DMAEMA)Viologen surfaces as a function of exposure time in the $D$. desulfuricans inoculated SSMB medium. Reprinted with permission from Yuan et al. (2009c). Copyright 2009 Wiley Periodicals Inc. was performed to use as the surface initiator for initiating ATRP of $4 \mathrm{VP}$. The pendent tertiary amino groups in the side chains of the P4VP brushes were finally quaternized by bromohexane to give rise to antibacterial functionality (Yuan et al., 2010a). The antibacterial and electrochemical studies showed that except for their high antibacterial capability to inhibit bacterial adhesion (or the formation of biofilm), the resulting $\mathrm{TiO}_{2} / \mathrm{QP} 4 \mathrm{VP}$ hybrid coatings could significantly increase corrosion resistance of stainless steel coupons to biocorrosion induced by anaerobic D. desulfuricans. The authors also claimed that the high corrosion resistance of the prepared inorganic-organic coatings resulted from combined protection properties of inner $\mathrm{TiO}_{2}$ multilayers and outer polycationic P4VP brushes. The same research group further prepared antibacterial inorganic-organic hybrid coatings using consecutive surface-initiated ATRP to mitigate biocorrosion (Yang et al., 2014). The well-defined inorganicorganic hybrid consisted of a polysilsesquioxane inner layer and quaternized PDMAEMA outer brushes. Electrochemical results demonstrated a dramatic increase in corrosion resistance of the coatings for the cross-linked poly(3-(trimethoxysilyl)-propyl methacrylate), or polysilsesquioxane, inner layers, although the quaternized PDMAEMA outer counterpart containing quaternary ammonium moieties can simultaneously endow the hybrid coatings with biocidal and anticorrosion properties. It is evident that the inner inorganic layers generally provide a durable, compact, and corrosion-resistant coating to aggressive electrolytes, and thereby retard the diffusion of aggressive anions onto the metal surface.

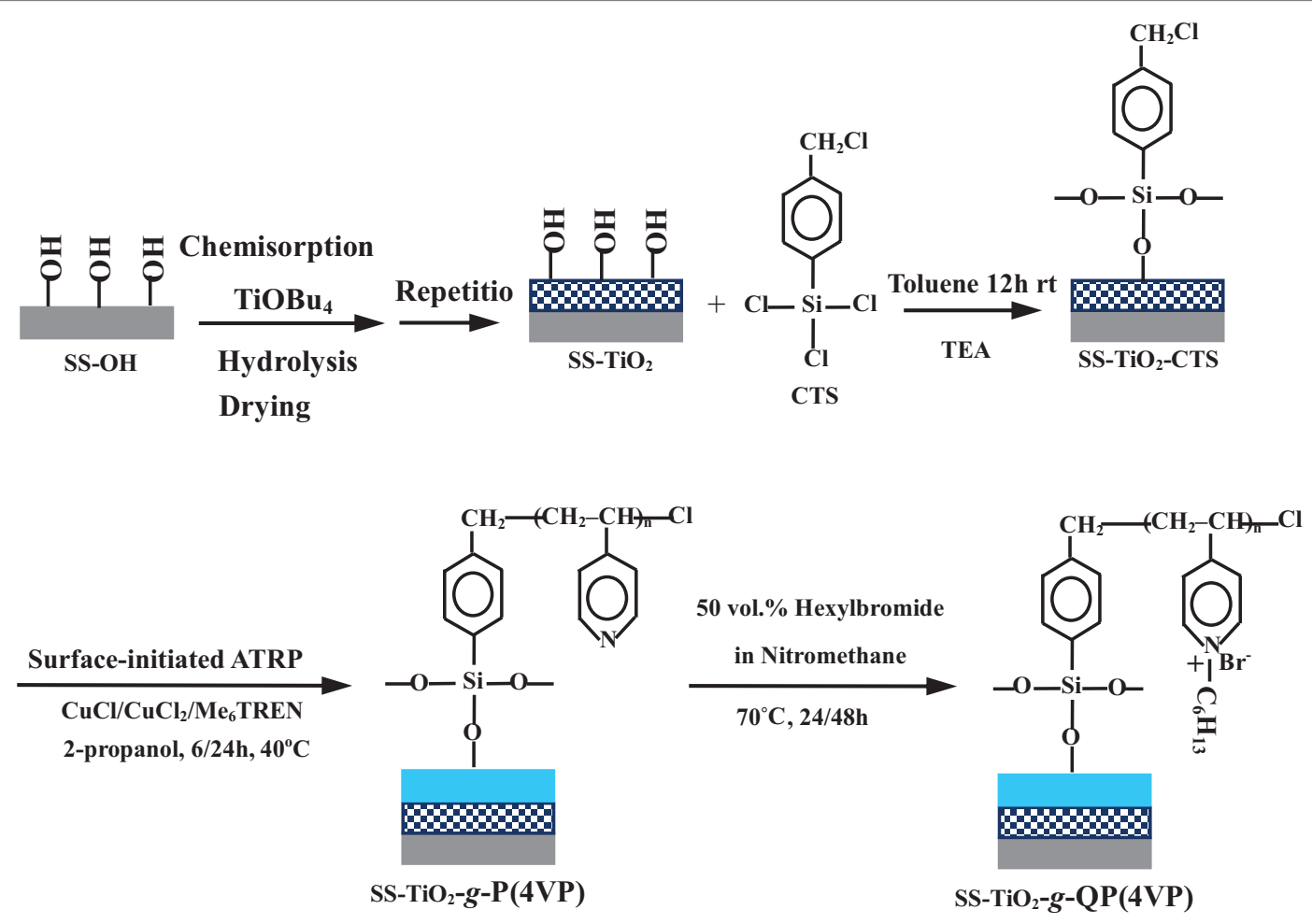

FIGURE 6 | Process in preparing organic/inorganichybrid coatings via combination of layer-by-layer sol-gel deposition and surface-initiated atom transfer radical polymerization of 4-vinyl pyridine. Reprinted with permission from Yuan et al. (2010a). Copyright 2009 American Chemical Society. 


\section{CONDUCTIVE POLYMERS IN COMBATING BIOCORROSION}

Conductive polymers are now regarded as the most promising replacement of chromate ion coatings for the control of corrosion due to their environmental stability, high conductivity, and unique redox mechanisms. Many mechanisms of conducting polymers to provide a corrosion protection ability have been proposed, they include their role to act as barriers and inhibitors, protection of anodic dissolution, and mediation of oxygen reduction (Shi et al., 2006). Among all the conducting polymers, polypyrrole (PPy), polyaniline (PANI), and polythiophene (PBT) have been widely employed as anticorrosion coatings for aluminum, mild steel, stainless steels, copper, and its alloys. Recently, different research groups have found that PANI exhibited the antibacterial ability against Gram-negative Escherichia coli and Gram-positive Staphylococcus aureus (Liu et al., 2008; Yuan et al., 2010b). It was reported that this phenomenon was ascribed to the formation of positively charged nitrogen due to the protonation reaction, i.e., some PANI of the emeraldine salt form converted to the leucoemeraldine salt form (Shi et al., 2006). Liu et al. (2008), attempted to synthesize conducting polymer microspheres of poly( $N$-methylaniline) (PNMA) using oxidative polymerization of $\mathrm{N}$-methylaniline. The experimental results showed that the PNMA microspheres inhibited the growth and proliferation of SRB and remarkably reduced the corrosion rate of carbon steel. The good antibacterial performance of PNMA in novolac epoxy coatings toward SRB was ascertained as well. Owing to their good corrosion protection ability and antimicrobial functionality to SRB, conductive polymers are, therefore, a very promising choice for biocorrosion inhibition.

Conventionally, the conductive polymer coatings are synthesized on metal surfaces byelectrochemical polymerization. The major concern of conductive polymer coatings prepared by electrochemical polymerization is their poor adhesion on the substrate surfaces. The adhesion force of conductive polymer coatings on the metal surface depends mainly on non-specific interactions, such as adsorption and polymer-metal complex formation. This results in a lack of chemical stability, as well as the reduction of barrier capability of coatings (Lv et al., 2014). In light of this, the conductive polymer coatings have been constructed on metal surfaces through covalent interactions for biocorrosion protection (Videla and Herrera, 2009; Wan et al., 2009). Wan et al. (2009) attempted to build up Ag nanoparticles (Ag Nps)-coupled bithiophene (BT) hybrid films on a copper substrate surface to inhibit biofilm formation and the subsequent corrosion induced by SRB. As shown in Figure 7, a uniform monolayer of 2,2'-BT was immobilized on the copper substrates via a self-assembly reaction, followed by grafting of poly (2,2'-bithiophene) (PBT) films via oxidative graft polymerization of 2,2'-bithiophene. Subsequently, $\mathrm{Ag}^{+}$was loaded on the PBT chains by the chemical affinity of sulfur for $\mathrm{Ag}^{+}$, and reduction reaction was performed to convert silver ions to silver nanoparticles (Figure $\mathbf{7 b}$ ). The experimental results revealed that the anticorrosion ability of the $\mathrm{PBT}$ films and the antibacterial capability of the immobilized Ag NPs could be effectively combined to inhibit SRB-induced biocorrosion on copper substrates. The same research group further proposed a novel environmentally benign approach to synthesize antibacterial conductive polymer coatings on the surfaces of mild steel by combination of surface-initiated ATRP and thermal curing reaction (Videla and Herrera, 2009). The epoxy groupscontaining poly(glycidyl methacrylate) (PGMA) brushes were first grafted from chlorosulfonyl-terminated surfaces of mild steel via surface-initiated ATRP of GMA, followed by thermal curing of the emeraldine (EM) salt form of PANI onto the PGMA chains. This resulted in strongly adhered and crosslinked PGMA-c-PANI bilayer coatings on the mild steel surface. The PGMA-c-PANI bilayer coating was further quaternized via $\mathrm{N}$-alkylation to yield a biocidal functionality. The results of antibacterial assay and electrochemical analysis showed that the outer cross-linked PANI layer significantly increased the pore resistance of the coatings, and also rendered the PGMA$c$-PANI bilayer coatings with an antimicrobial capability to effectively inhibit bacterial adhesion. The experimental results further demonstrated that the so-synthesized PGMA-c-PANI bilayer coating exhibited a high inhibition efficiency (up to 95\%) against corrosion induced by microorganism throughout the exposure period. Using a similar thermally curing method, Lv et al. (2014) fabricated poly(vinylbenzyl chloride)-PANI dual layers to control microbially induced corrosion by SRB. PANI layer was first thermally cured onto the epoxy groups-containing silanized mild steel, and then thermally induced $\mathrm{N}$-alkylation of PANI was carried out by hydrophobic 4-vinylbenzyl chloride $(\mathrm{VBzCl})$ to produce antibacterial poly(vinylbenzyl chloride)quaternized PANI (i.e., QPANI-PVBC) bilayer coatings on the mild steel surface. Antibacterial array results demonstrated a dramatic decrease in live SRB cells on the as-synthesized steel surfaces, while the QPANI-PVBC dual layer coatings conferred high barrier capability and corrosion resistance on the surfaces of mild steel coupons with an inhibition efficiency more than $97 \%$ against biocorrosion induced by SRB.

More recently, Yuan et al. (2012) fabricated a nitrogenrich dual layer coating of poly(4-vinylaniline)-polyaniline (i.e., PVAn-PANI) on stainless steel by combination of surfaceinitiated ATRP and in situ chemical oxidative graft polymerization. As shown in Figure 8, surface-initiated ATRP of 4-vinylaniline (VAn) was first carried out to graft PVAn brushes onto the salinized surface of stainless steel, and then chemical oxidative graft polymerization of aniline was performed from the PVAn-grafted surface to form PVAn-PANI bilayers. The as-synthesized surface was further $N$-alkylated by bromohexane to generate polcationic PANI with antibacterial activity. The antibacterial and anticorrosion performance of the quaternized PVAn-PANI bilayers were ascertained by bactericidal array and electrochemical studies, respectively. The experimental results demonstrated that the as-synthesized stainless steel not only showed high killing efficiency of bacterial attachment but also remained stable and highly resistant under the synergistic attack of aggressive anions $\left(\mathrm{Cl}^{-}\right.$and $\left.\mathrm{S}^{2-}\right)$ and $D$. desulfuricans. One-pot method was designed to chemically synthesize dedoped bromosubstituted polyaniline (Br-PANI). Epoxy resin composite coatings containing 2.0 weight $\%$ of dedoped Br-PANIs (EBP) were 


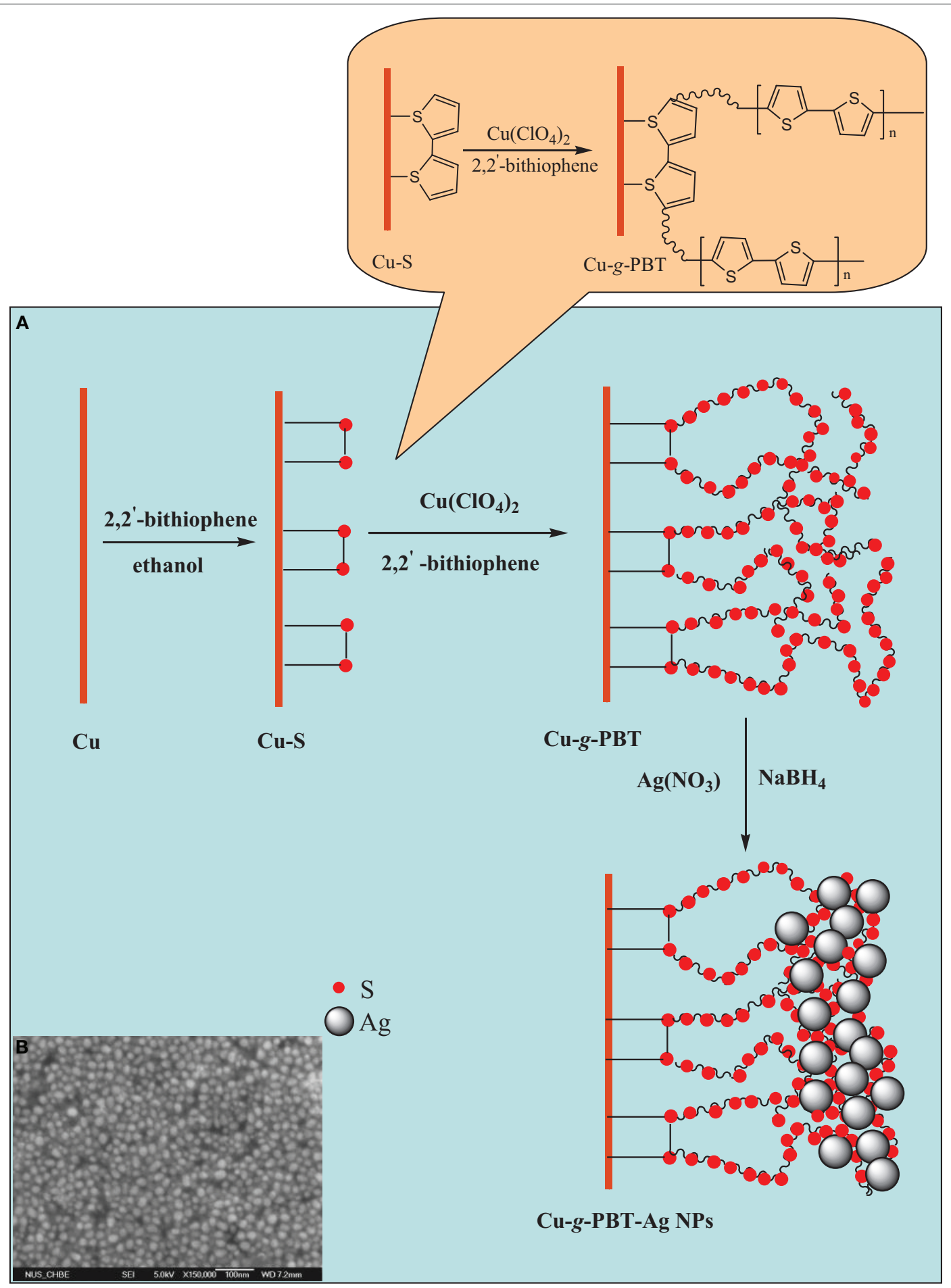

FIGURE 7 | (A) Process of oxidative graft polymerization of 2,2-bithiophene (BT) from the BT monolayer-immobilized copper surface via self-assembly method, and subsequent immobilization of silver nanoparticles (Ag Nps). (B) FESEM images of the Ag Nps-immobilized surface. Reprinted with permission from Videla and Herrera (2009). Copyright 2010 American Chemical Society.

also prepared (Cai et al., 2018). Scanning electron microscopy, organic elemental analysis, and XPS analysis demonstrated that Br-PANIs with different $\mathrm{Br} / \mathrm{N}$ molar ratios were successfully synthesized. The anticorrosion and antifouling performances of EBP coatings were characterized by accelerated immersion test, electrochemical impedance spectroscopy (EIS), XPS, antibacterial test, and field test. Results showed that EBP coatings presented an excellent protection after 100 days of immersion 


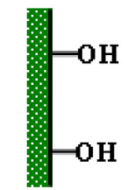

SS-OH

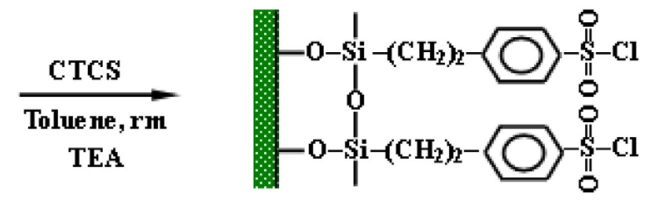

SS-Cl<smiles>CCCc1ccccc1CCCc1ccc(N)cc1</smiles>
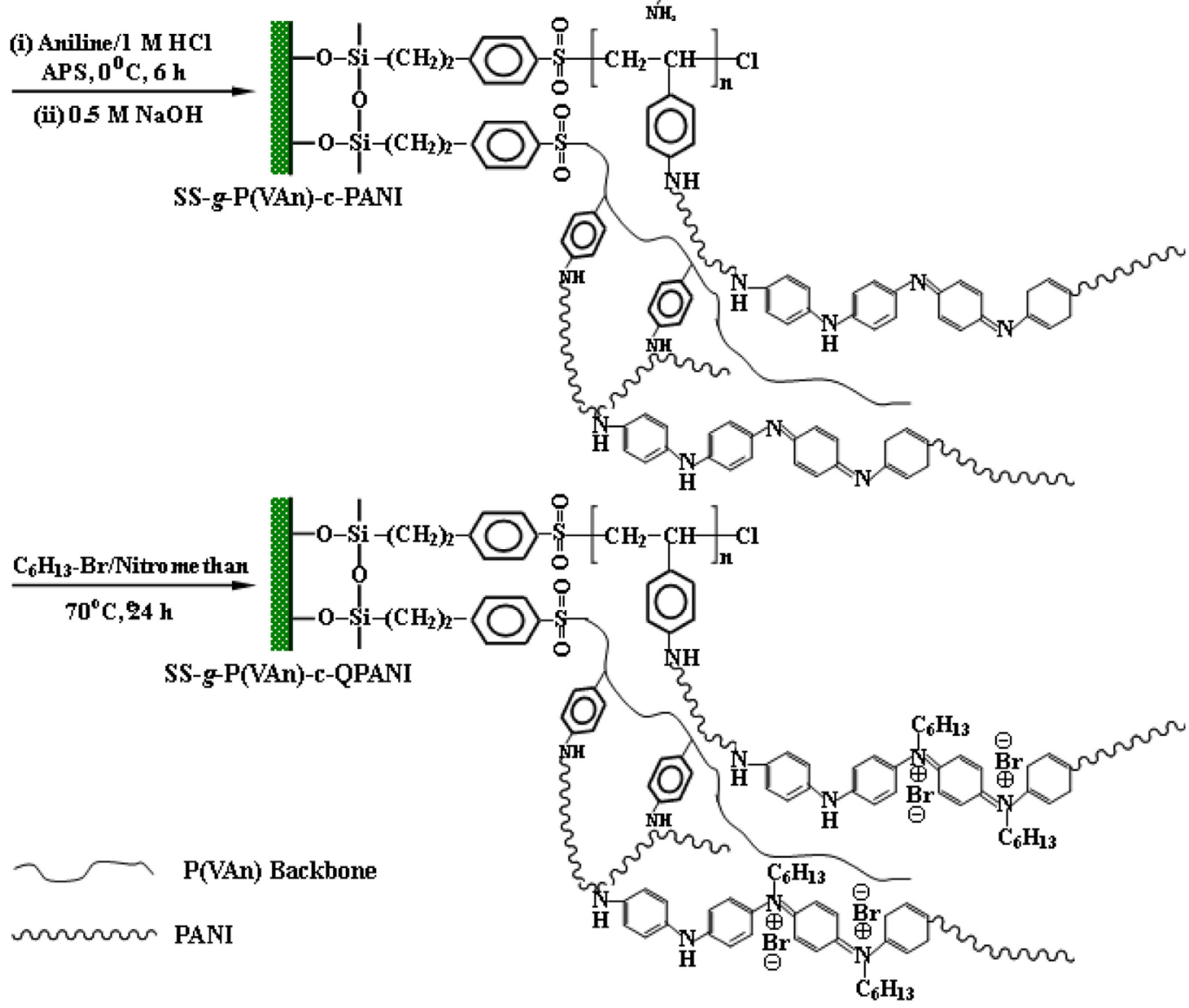

FIGURE 8 | Schematic diagram illustrating the process of surface-initiated atom transfer radical polymerization of 4-vinylaniline (VAn), subsequent chemical oxidative polymerization of aniline on the PVAn-grafted surface to generate the PVAn- $g$-polyaniline bilayer-coated surfaces and finally $N$-alkylation to give rise to antibacterial functionality. Reprinted with permission from Yuan et al. (2012). Copyright 2012 American Chemical Society.

in a 12.0 weight $\% \mathrm{NaCl}$ solution at $95^{\circ} \mathrm{C}$. Moreover, EBP coatings had a better antibacterial and antifouling performance than a pure epoxy coating and a dedoped PANI composite coating. In particular, the anticorrosion and antifouling abilities of EBP improved with the increase of the bromine content (Cai et al., 2018). In conclusion, the success of biocorrosion control through antibacterial conductive polymer coatings offers a great potential for mitigating and preventing biocorrosion in the future. 


\section{CONCLUSION}

The mitigation of biocorrosion is mainly based on preventing or minimizing the bacterial adhesion and the development of biofilms, since the formation of biofilms on substrate surfaces has been extensively considered as the primary step in initiating biocorrosion. Besides the conventional biocide treatment and beneficial biofilm control, polymer coating application is another major corrosion protection strategy against biocorrosion. The traditional polymers used in biocorrosion protection mainly include polyurethane, silicone, epoxy resins, etc. Due to their susceptibility to microbial degradation, antibacterial agents are frequently incorporated into the polymer matrix to endow the polymer coatings with biocidal functionality for avoiding the bacterial adhesion and biofilm formation. On the other hand, most of the traditional polymer coatings are prepared by the approaches of dip coating or spin coating, and there are concerns of adhesion between the polymer coatings and the metal substrate surface. To improve the stability and the durability of polymer coatings, the polymer coatings are synthesized on the metal surface via covalent interactions. Some vinyl monomers containing tertiary amino groups are polymerized or copolymerized via a surface-initiated ATRP, followed by quaternization to introduce an antimicrobial activity. As the grafted antibacterial polymer coatings have a limited corrosion resistance, the inorganic coatings are first deposited on the metal surface using a LBL self-assembly deposition or a surface-initiated ATRP to serve as the primer coating, and thus substantially enhancing

\section{REFERENCES}

Aguirre, J., Daille, L., Fischer, D. A., Galarce, C., Pizarro, G., Vargas, I., et al. (2017). Study of poly(3, 4-ethylendioxythiphene) as a coating for mitigation of biocorrosion of AISI 304 stainless steel in natural seawater. Prog. Org. Coat. 113, 175-184. doi:10.1016/j.porgcoat.2017.09.009

Al-Darbi, M. M., Muntasser, Z. M., Tango, M., and Islam, M. R. (2002). Control of microbial corrosion using coatings and natural additives. Energ. Source 24, 1009-1018. doi:10.1080/00908310290086941

Ananda Kumar, S., Balakrishnan, T., Alagar, M., and Denchev, Z. (2006). Development and characterization of silicone/phosphorus modified epoxy materials and their application as anticorrosion and antifouling coatings. Prog. Org. Coat. 55, 207-217. doi:10.1016/j.porgcoat.2005.10.001

Arps, P. J., Xu, L. C., Green, R. M., Wood, T. K., Mansfeld, F. B., Syrett, B. C., etal. (2003). "Field evaluation of corrosion control using regenerative biofilms (CCURB)," in Corrosion/2003, paper 03714 (Houston, TX: NACE International). Paper No. 03714.

Badawi, A. M., Hegazya, M. A., El-Sawy, A. A., Ahmed, H. M., and Kamel, W. M. (2010). Novel quaternary ammonium hydroxide cationic surfactants as corrosion inhibitors for carbon steel and as biocides for sulfate reducing bacteria (SRB). Mater. Chem. Phys. 124, 458-465. doi:10.1016/j.matchemphys. 2010.06.066

Barriosa, C. A., Xu, Q. W., Cutright, T., and Newbya, B. M. Z. (2005). Incorporating zosteric acid into silicone coatings to achieve its slow release while reducing fresh water bacterial attachment. Colloid Surf. B 41, 83-93. doi:10.1016/j. colsurfb.2004.09.009

Beech, I. B., and Sunner, J. (2004). Biocorrosion: towards understanding interactions between biofilms and metals. Curr. Opin. Biotechnol. 15, 181-186. doi:10.1016/j.copbio.2004.05.001

Bentham, R. H., Morton, L. H. G., and Allen, N. G. (1987). Rapid assessment of the microbial deterioration of polyurethanes. Int. Biodet. 23, 377-386. doi:10.1016/ 0265-3036(87)90026-1 the compactness of inorganic-organic hybrid coatings. For the corrosion-resistant conductive polymers, they can be grafted from metal surfaces via an oxidative graft polymerization to yield conductive polymer coatings. Alternatively, the conductive polymer are immobilized or cross-linked on the grafted coating surface via a thermal curing reaction. The antibacterial properties are also rendered to the conductive polymer coatings through a quaternization reaction or a coupling of silver nanoparticles. In summary, covalently immobilized polymer coatings that simultaneously possess antibacterial and anticorrosion properties are potentially useful in combating biocorrosion under harsh environments.

\section{AUTHOR CONTRIBUTIONS}

SY organized the review and finalized the manuscript. JG and LL wrote the traditional polymeric coatings (i.e., second section). SP wrote the antibacterial polymeric coatings (i.e., third section). WJ and BL wrote the conductive polymer coatings (i.e., fourth section).

\section{FUNDING}

The authors would like to acknowledge the financial assistance of the National Natural Science Foundation of China (No. 21676169 and 21576034) and the National Key R\&D Program of China (2016YFB0301701).

Beveridge, T., and Doyle, R. (eds) (1989). Metals, Ions and Bacteria. New York: John Wiley \&Sons.

Brady, R. F. (1999). Properties which influence marine fouling resistance in polymers containing silicon and fluorine. Prog. Org. Coat. 35, 31-35. doi:10.1016/ S0300-9440(99)00005-3

Brady, R. F., and Singer, I. L. (2000). Mechanical factors favoring release from fouling release coatings. Biofouling 15, 73-81. doi:10.1080/08927010009386299

Braunecker, W. A., and Matyjaszewski, K. (2007). Controlled/living radical polymerization: features, developments, and perspectives. Prog. Polym. Sci. 32, 93-146. doi:10.1016/j.progpolymsci.2006.11.002

Cai, W., Wang, J., Quan, X., Zhao, S., and Wang, Z. (2018). Antifouling and anticorrosion properties of one-pot synthesized dedoped bromo-substituted polyaniline and its composite coatings. Surf. Coat Technol. 334, 7-18. doi:10.1016/j. surfcoat.2017.10.076

Characklis, W. G., and Marshall, M. C. (eds) (1990). Biofilms. New York: John Wiley \& Sons.

Cheung, C. W. S., and Beech, I. B. (1996). The use of biocides to control sulphatereducing bacteria in biofilms on mild steel surfaces. Biofouling 9, 231-249. doi:10.1080/08927019609378305

Choi, S. B., Jepperson, J., Jarabek, L., Thomas, J., Chisholm, B., and Boudjouk, P. (2007). Novel approach to anti-fouling and fouling-release marine coatings based on dual-functional siloxanes. Macromol. Symp. 49, 660-667. doi:10.1002/ masy. 200750452

Costerton, J. W. (1987). "Bacterial biofilms in relation to internal corrosion monitoring and biocide strategies," in Corrosion/87, paper 870314 (Houston, TX: NACE International).

Crum, M. G., Reynolds, R. J., and Hedrick, H. G. (1967). Microbial penetration and utilization of organic aircraft fuel-tank coatings. Appl. Microbiol. 15, 1352-1355.

Donlan, R. M., and Costerton, J. W. (2002). Biofilms: survival mechanisms of clinically relevant microorganisms. Clin. Microbiol. Rev. 15, 167-193. doi:10.1128/ CMR.15.2.167-193.2002 
Dubiel, M., Hsu, C. H., Chien, C. C., Mansfeld, F., and Newman, D. K. (2002). Microbial iron respiration can protect steel from corrosion. Appl. Environ. Microbiol. 68, 1440-1445. doi:10.1128/AEM.68.3.1440-1445.2002

Dunne, W. M. (2002). Bacterial adhesion: seen any good biofilms lately. Clin. Microbiol. Rev. 15, 155-166. doi:10.1128/CMR.15.2.155-166.2002

Edwards, D. P., Nevell, T. G., Plunkett, B. A., and Ochiltree, B. C. (1994). Resistance to marine fouling of elastomeric coatings of some poly(dimethylsiloxanes) and poly (dimethyldiphenylsiloxanes). Int. Biodet. Biodegrad. 34, 349-359. doi:10.1016/0964-8305(94)90093-0

Estarlich, F. F., Lewey, S. A., Nevell, T. G., Thorpe, A. A., Tsibouklis, J., and Upton, A. C. (2000). The surface properties of some silicone and fluorosilicone coating materials immersed in seawater. Biofouling 16, 263-275. doi:10.1080/ 08927010009378450

Fan, X. W., Lin, L. J., Dalsin, J. L., and Messersmith, P. B. (2005). Biomimetic anchor for surface-initiated polymerization from metal substrates. J. Am. Chem. Soc. 127, 15843-15847. doi:10.1021/ja0532638

Flemming, H. C. (1998). Relevance of biofilms for the biodeterioration of surfaces of polymeric materials. Polym. Degrad. Stabil. 59, 309-315. doi:10.1016/ S0141-3910(97)00189-4

Franklin, M. J., Nivens, D. E., Vass, A. A., Mittelman, M. W., Jack, R. F., Dowling, N. J. E., et al. (1991). Effect of chlorine and chlorine/bromine biocide treatments on the number and activity of biofilm bacteria and on carbon steel corrosion. Corrosion 47, 128-134. doi:10.5006/1.3585228

Frignani, A., Tassinari, M., Mészãros, L., and Trabanelli, G. (1991). The use of electrochemical impedance spectroscopy to study ARMCO iron corrosion in acid solutions inhibited by quaternary ammonium compounds. Corros. Sci. 32, 903-911. doi:10.1016/0010-938X(91)90033-L

Gardner, L. R., and Stewart, P. S. (2002). Action of glutaraldehyde and nitrite against sulfate-reducing bacterial biofilms. J. Ind. Microbiol. Biotechnol. 29, 354-360. doi:10.1038/sj.jim.7000284

Grover, N., Plaks, J. G., Summers, S. R., Chado, G. R., Schurr, M. J., and Kaar, J. L. (2016). Acylase-containing polyurethane coatings with anti-biofilm activity. Biotechnol. Bioeng. 113, 2535-2543. doi:10.1002/bit.26019

Gu, J. D., Roman, M., Esselman, T., and Mitchell, R. (1998a). The role of microbial biofilms in deterioration of space station candidate materials. Int. Biodet. Biodegrad. 41, 25-33. doi:10.1016/S0964-8305(97)00070-X

Gu, J. D., Mitchell, R., Mitton, B., and Ford, T. E. (1998b). Microbial degradation of polymeric coatings measured by electrochemical impedance spectroscopy. Biodegradation 9, 39-45. doi:10.1023/A:1008252301377

Guezennec, J. G. (1994). Cathodic protection and microbially induced corrosion. Int. Biodeter. Biodegr. 34, 275-288. doi:10.1016/0964-8305(94)90088-4

Guiamet, P. S., and Gómez de Saravia, S. (2005). Laboratory studies of biocorrosion control using traditional and environmentally friendly biocides: an overview. Lat. Am. Appl. Res. 35, 295-300.

Hamilton, W. A. (1985). Sulphate-reducing bacteria and anaerobic corrosion. Annu. Rev. Microbiol. 139, 195-217. doi:10.1146/annurev.mi.39.100185. 001211

Haque, H., Cutright, T. J., and Newby, B. M. Z. (2005). Effectiveness of sodium benzoate as a freshwater low toxicity antifoulant when dispersed in solution and entrapped in silicone coatings. Biofouling 21, 109-119. doi:10.1080/ 08927010500222551

Heitz, E., Flemming, H. C., and Sand, W. (eds) (1996). Microbially Influenced Corrosion of Materials. Berlin: Springer Verlag.

Hernandez, G., Kucera, V., Thierry, D., Pedersen, A., and Hermansson, M. (1994). Corrosion inhibition of steel by bacteria. Corrosion 50, 603-608. doi: $10.5006 / 1.3293532$

Houghton, D., Smith, R. N., and Eggins, H. O. (eds) (1988). Biodeterioration 7. London, New York: Elsevier.

Huang, J., Koepsel, R. R., Murata, H., Wu, W., and Lee, S. B. (2008). Nonleaching antibacterial glass surfaces via "grafting onto": the effect of the number of quaternary ammonium groups on biocidal activity. Langmuir 24, 6785-6795. doi:10.1021/la8003933

Ilhan-Sungur, E., Cansever, N., and Cotuk, A. (2007). Microbial corrosion of galvanized steel by a freshwater strain of sulphate reducing bacteria (Desulfovibrio sp.). Corros. Sci. 49, 1097-1109. doi:10.1016/j.corsci.2006. 05.050

Ilhan-Sungur, E., and Cotuk, A. (2010). Microbial corrosion of galvanized steel in a simulated recirculating cooling tower system. Corros. Sci 52, 161-171. doi:10.1016/j.corsci.2009.08.049
Javaherdashti, R. A. (1999). A review of some characteristics of MIC caused by sulfate-reducing bacteria: past, present and future. Anti-Corros. Method. Mater. 46, 173-180. doi:10.1108/00035599910273142

Jayaraman, A., Earthman, J. C., and Wood, Y. K. (1997). Corrosion inhibition by aerobic biofilms on SAE 1018 steel. Appl. Microbiol. Biotechnol. 47, 62-68. doi:10.1007/s002530050889

Jayaraman, A., Hallock, P. J., Carson, R. M., Lee, C. C., Mansfeld, F. B., and Wood, T. K. (1999a). Inhibiting sulfate-reducing bacteria in biofilms on steel with antimicrobial peptides generated in situ. Appl. Microbiol. Biotechnol. 52, 267-275. doi:10.1007/s002530051520

Jayaraman, A., Örnek, D., Duarte, D. A., Lee, C. C., Mansfeld, F. B., and Wood, T. K. (1999b). Inhibiting sulfate-reducing bacteria in biofilms by expressing the antimicrobial peptides indolicidin and bactenecin. Appl. Microbiol. Biotechnol. 52, 787-790.

Jayaraman, A., Mansfeld, F. B., and Wood, T. K. (1999c). Inhibiting sulfatereducing bacteria in biofilms by expressing the antimicrobial peptides indolicidin and bactenecin. J. Ind. Microbiol. Biot. 22, 167-175. doi:10.1038/sj.jim.2900627

Jones-Meehan, J., Walch, M., Little, B. J., Ray, R. I., and Mansfeld, F. B. (1992). "ESEM/EDS, SEM/EDS and EIS studies of coated 4140 steel exposed to marine, mixed microbial communities including sulfate-reducing bacteria," in ASME International Power Generation Conference (Atlanta, GA: ASME), 1-16.

Kay, M. J., McCabe, R. W., and Morton, L. H. G. (1993). Chemical and physical changes occurring in polyester polyurethane during biodegradation. Int. Biodet. Biodegrad. 31, 209-225. doi:10.1016/0964-8305(93)90006-N

Kennedy, H. (2002). "Protection of reinforced concrete pipe against microbial induced corrosion," in Corrosion/1997, paper 970332 (Houston, TX: NACE International).

Koch, G. H., Brongers, M. P. H., Thompson, N. G., Virmani, Y. P., and Payer, J. H. (2002). Corrosion Costs and Preventive Strategies in the United States. Report FHWA-RD-01-156. Houston, TX: NACE International.

Koplin, S. A., Lin, S., and Domanski, T. (2008). Evaluation of the antimicrobial activity of cationic polyethylenimines on dry surfaces. Biotechnol. Prog. 24, 1160-1165. doi:10.1002/btpr.32

Kopteva, Z. P., Zanina, V. V., and Kozlova, I. A. (2004). Microbial corrosion of protective coatings. Surf. Eng. 20, 275-280. doi:10.1179/0267084042 25016463

Kugel, A., Stafslien, S., and Chisholm, B. J. (2011). Antimicrobial coatings produced by "tethering" biocides to the coating matrix: a comprehensive review. Prog. Org. Coat 72, 222-252. doi:10.1016/j.porgcoat.2011.07.004

Kus, E., Grunlan, M. A., Weber, W. P., and Mansfeld, F. B. (2005). Evaluation of nontoxic polymer coatings with potential biofoul release properties using EIS. J Electrochem. Soc. 152, B236-B243. doi:10.1149/1.1923727

Lebrini, M., Bentiss, F., Chihib, N. E., Jama, C., Hornez, J. P., and Lagrenée, M. (2008). Polyphosphate derivatives of guanidine and urea copolymer: inhibiting corrosion effect of armco iron in acid solution and antibacterial activity. Corros. Sci. 50, 2914-2918. doi:10.1016/j.corsci.2008.07.003

Little, B. J., Lee, J., and Ray, R. (2007). A review of 'green'strategies to prevent or mitigate microbiologically influenced corrosion. Biofouling 23, 87-97. doi:10.1080/08927010601151782

Little, B. J., Ray, R. I., Wagner, P. A., Jones-Meehan, J., Lee, C. C., and Mansfeld, F. B. (1999). Spatial relationships between marine bacteria and localized corrosion on polymer coated steel. Biofouling 13, 301-321. doi:10.1080/ 08927019909378387

Liu, H. F., Huang, L., Huang, Z., Qi, G. T., Kei, S., and Yutaka, H. (2008). Preparation of conducting poly N-methylaniline microsphere and its antibacterial performance to sulfate reducing bacteria. J. Wuhan Univer. Technol. Mater. Sci. Ed. 23, 536-540. doi:10.1007/s11595-006-4536-6

Lv, L., Yuan, S. J., Zheng, Y., Liang, B., and Pehkonen, S. O. (2014). Surface modification of mild steel with thermally cured antibacterial poly (vinylbenzyl chloride)-polyaniline bilayers for effective protection against sulfate reducing bacteria induced corrosion. Ind. Eng. Chem. Res. 53, 12363-12378. doi:10.1021/ ie $501654 \mathrm{~b}$

Mansfeld, F. B., Han, L. T., Lee, C. C., and Zhang, G. (1998). Evaluation of corrosion protection by polymer coatings using electrochemical impedance spectroscopy and noise analysis. Electrochim. Acta 43, 2933-2945. doi:10.1016/ S0013-4686(98)00034-6

Mansfeld, F. B., Xiao, H., Han, L. T., and Lee, C. C. (1997). Electrochemical impedance and noise data for polymer coated steel exposed at remote marine test sites. Prog. Org. Coat. 30, 89-100. doi:10.1016/S0300-9440(96)00675-3 
Mazumder, M. M., Trigwell, S., Ali, N., Mazumder, M. K., and Mehta, J. L. (2003). Corrosion resistance of polyurethane-coated nitinol cardiovascular stents. J. Biomater. Sci. Polymer Edn 14, 1351-1362. doi:10.1163/ 156856203322599699

Miller, R. N., Herron, W. C., Krigens, A. G., Cameron, J. L., and Terry, B. M. (1964). Microorganisms cause corrosion in aircraft fuel tanks. Mater. Prot. 3, 60-67.

Milovic, N. M., Wang, J., Lewis, K., and Klibanov, A. M. (2005). Immobilized $\mathrm{N}$-alkylated polyethylenimine avidly kills bacteria by rupturing cell membranes with no resistance developed. Biotechnol. Bioeng. 90, 715-722. doi:10.1002/ bit. 20454

Muntasser, Z., Al-Darbi, M., Tango, M., and Islam, M. R. (2002). "Prevention of microbiologically influenced corrosion using coatings," in Corrosion/2002, paper 02029 (Houston, TX: NACE International).

Negm, N. A., and Aiad, I. A. (2007). Synthesis and characterization of multifunctional surfactants in oil-field protection applications. J. Surfactants Deterg. 10, 87-92. doi:10.1007/s11743-007-1016-8

Nevell, T. G., Edwards, D. P., Davis, A. J., and Pullin, R. A. (1996). The surface properties of silicone elastomers exposed to seawater. Biofouling 10, 199-212. doi:10.1080/08927019609386280

Neville, A., Hodgkiess, T., and Destriau, X. (1998). Initiation and propagation of localised corrosion on stainless steels in seawater containing high biocide concentrations. Corros. Sci. 40, 715-730. doi:10.1016/S0010-938X(97) 00173-X

Örnek, D., Jayaraman, A., Syrett, B., Hsu, C. H., and Wood, T. K. (2002). Pitting corrosion inhibition of aluminum 2024 by Bacillus biofilms secreting polyaspartate or $\gamma$-polyglutamate. Appl. Microbiol. Biotechnol. 58, 651-657. doi:10.1007/ s00253-002-0942-7

Pedersen, A., and Hermansson, M. (1989). The effects on metal corrosion by Serratia marcescens and a Pseudomonas sp. Biofouling 1, 313-322. doi:10.1080/ 08927018909378119

Pedersen, A., and Hermansson, M. (1991). Inhibition of metal corrosion by bacteria. Biofouling 3, 1-11. doi:10.1080/08927019109378157

Pedersen, A., Kjelleberg, S., and Hermansson, M. (1988). A screening method for bacterial corrosion of metals. J. Microbiol. Methods 8, 191-198. doi:10.1016/ 0167-7012(88)90001-2

Qi, Y., Li, J., Liang, R., Ji, S., Li, J., and Liu, M. (2017). Chemical additives affect sulfate reducing bacteria biofilm properties adsorbed on stainless steel 316L surface in circulating cooling water system. Front. Env. Sci. Eng. 11:14. doi:10.1007/s11783-017-0917-7

Rajasekar, A., and Ting, Y. P. (2011). Inhibition of biocorrosion of aluminum 2024 aeronautical alloy by conductive ladder polymer poly (o-phenylenediamine). Ind. Eng. Chem. Res. 50, 2040-2046. doi:10.1021/ie101678x

Ramezanzadeh, B., Ghasemi, E., Mahdavian, M., Changizi, E., and Mohamadzadeh Moghadam, M. H. (2015). Covalently-grafted graphene oxide nanosheets to improve barrier and corrosion protection properties of polyurethane coatings. Carbon N. Y. 93, 555-573. doi:10.1016/j.carbon.2015.05.094

Schweinberg, D. P., and Ashworth, V. (1988). The inhibition of the corrosion of pure iron in $0.5 \mathrm{M}$ sulphuric acid by n-alkyl quaternary ammonium iodides. Corros. Sci. 28, 539-545. doi:10.1016/0010-938X(88)90022-4

Seal, K. J., and Pathirana, R. A. (1982). The microbiological susceptibility of polyurethanes. A review. Int. Biodet. Bull. 18, 81-85.

Seter, M., Thomson, M. J., Stoimenovski, J., MacFarlane, D. R., and Forsyth, M. (2012). Dual active ionic liquids and organic salts for inhibition of microbially influenced corrosion. Chem. Commun. 48, 5983-5985. doi:10.1039/c2cc32375c

Shi, N., Guo, X., and Jiang, H. (2006). Antibacterial effect of the conducting polyaniline. J. Mater. Sci. Technol. 22, 289-290.

Spinks, G. M., Dominis, A. J., Wallace, G. G., and Tallman, D. E. (2002). Electroactive conducting polymers for corrosion control. J. Solid. State Electrochem. 6, 73-84. doi: $10.1007 / \mathrm{s} 100080100212$

Stobie, N., Duffy, B., Hinder, S. J., McHale, P., and McCormack, D. E. (2009). Silver doped perfluoropolyether-urethane coatings: antibacterial activity and surface analysis. Colloids Surf. B Biointerfaces 72, 62-67. doi:10.1016/j.colsurfb. 2009.03.014

Sugama, T. (1995). Pectin copolymers with organosiloxane grafts as corrosionprotective coatings for aluminum. Mater. Lett. 25, 291-299. doi:10.1016/ 0167-577X(95)00173-5

Sugama, T., and Cook, M. (2000). Poly(itaconic acid)-modified chitosan coatings for mitigating corrosion of aluminum substrates. Prog. Org. Coat. 38, 79-87. doi:10.1016/S0300-9440(00)00077-1
Sugama, T., and DuVall, J. E. (1996). Polyorganosiloxane-grafted potato starch coatings for protecting aluminum from corrosion. Thin Solid Films 289, 39-48. doi:10.1016/S0040-6090(96)08814-1

Thomas, J., Choi, S. B., Fjeldheim, R., and Boudjouk, P. (2004). Silicones containing pendant biocides for antifouling coatings. Biofouling 20, 227-236. doi:10.1080/08927010400011229

Tiller, J. C., Lee, S. B., Lewis, K., and Klibanov, A. M. (2002). Polymer surfaces derivatized with poly (vinyl-N-hexylpyridinium) kill airborne and waterborne bacteria. Biotechnol. Bioeng. 79, 465-471. doi:10.1002/bit.10299

Tiwari, A., and Hihara, L. H. (2010). High performance reaction-induced quasiceramic silicone conversion coating for corrosion protection of aluminium alloys. Prog. Org. Coat. 69, 16-25. doi:10.1016/j.porgcoat.2010.04.020

Videla, H. A. (1996). Manual of Biocorrosion. Boca Raton, FL: CRC Lewis Publishers.

Videla, H. A. (2002). Prevention and control of biocorrosion. Int. Biodeter. Biodegr. 49, 259-270. doi:10.1016/S0964-8305(02)00053-7

Videla, H. A., de Saravia, S. G. G., Guiamet, P. S., and Allegreti, P. (2000). "Microbial degradation of film forming inhibitors and its possible effects on corrosion inhibition performance," in Corrosion/2000, paper 00386 (Houston, TX: NACE International).

Videla, H. A., Guiamet, P. S., Gómez de Saravia, S., Herrera, L. K., and Gaylarde, C. C. (2004). "Environmentally friendly approaches to inhibit biocorrosion: an overview," in Corrosion/2004, paper 04574 (Houston, TX: NACE International).

Videla, H. A., and Herrera, L. K. (2005). Microbiologically influenced corrosion: looking to the future. Int. Microbiol. 8, 169-180.

Videla, H. A., and Herrera, L. K. (2009). Understanding microbial inhibition of corrosion. A comprehensive overview. Int. Biodeterior. Biodegr. 63, 896-900. doi:10.1016/j.ibiod.2009.02.002

Viera, M. R., Guiamet, P. S., de Mele, M. F. L., and Videla, H. A. (1999). Use of dissolved ozone for controlling planktonic and sessile bacteria in industrial cooling systems. Int. Biodeter. Biodegr. 44, 201-207. doi:10.1016/S0964-8305 (99)00078-5

Wagner, P. A., Little, B. J., Hart, K. R., and Ray, R. I. (1996). Biodegradation of composite materials. Int. Biodeterior. Biodegr. 38, 125-132. doi:10.1016/09648305(96)84358-7

Wan, D., Yuan, S. J., Neoh, K. G., and Kang, E. T. (2009). Poly(glycidyl methacrylate)- polyaniline bilayer-modified mild steel for combating biocorrosion in seawater. J. Electrochem. Soc. 156, C266-C274. doi:10.1149/ 1.3151830

Watermann, B., Berger, H. D., Sonnichsen, H., and Willemsen, P. (1997). Performance and effectiveness of non-stick coatings in seawater. Biofouling 11, 101-118. doi:10.1080/08927019709378323

Yang, W. J., Neoh, K. G., Kang, E. T., Teo, S. L. M., and Rittschof, D. (2014). Polymer brush coatings for combating marine biofoulin. Prog. Polym. Sci. 39, 1017-1042. doi:10.1016/j.progpolymsci.2014.02.002

Ye, S. J., McClelland, A., Majumdar, P., Stafslien, S. J., Chisholm, B., and Chen, Z. (2008). Detection of tethered biocide moiety segregation to silicone surface using sum frequency generation vibrational spectroscopy. Langumir 24, 9686-9694. doi:10.1021/la800769z

Yesudass, S. A., Mohanty, S., Nayak, S. K., and Rath, C. C. (2017). Zwitterionicpolyurethane coatings for non-specific marine bacterial inhibition: a nontoxic approach for marine application. Eur. Polym. J. 96, 304-315. doi:10.1016/j. eurpolymj.2017.09.019

Yuan, S. J., Liu, C. K., Pehkonen, S. O., Bai, R. B., Neoh, K. G., Ting, Y. P., et al. (2009a). Surface functionalization of $\mathrm{Cu}-\mathrm{Ni}$ alloys via grafting of a bactericidal polymer for inhibiting biocorrosion by Desulfovibrio desulfuricans in anaerobic seawater. Biofouling 25, 109-125. doi:10.1080/ 08927010802578932

Yuan, S. J., Xu, F. J., Pehkonen, S. O., Ting, Y. P., Neoh, K. G., and Kang, E. T. (2009b). Grafting of antibacterial polymers on stainless steel via surface-initiated atom transfer radical polymerization for inhibiting biocorrosion by Desulfovibrio desulfuricans. Biotechnol. Bioeng. 103, 268-281. doi:10.1002/bit.22252

Yuan, S. J., Pehkonen, S. O., Ting, Y. P., Neoh, K. G., and Kang, E. T. (2009c). Inorganic- organic hybrid coatings on stainless steel by layer-by-layer deposition and surface-initiated atom-transfer-radical polymerization for combating biocorrosion. ACS Appl. Mater. Interfaces 1, 640-652. doi:10.1021/ am800182d

Yuan, S. J., Pehkonen, S. O., Ting, Y. P., Neoh, K. G., and Kang, E. T. (2010a). Antibacterial inorganic-organic hybrid coatings on stainless steel via conse- 
cutive surface-initiated atom transfer radical polymerization for biocorrosion prevention. Langmuir 26, 6728-6736. doi:10.1021/la904083r

Yuan, S. J., Pehkonen, S. O., Liang, B., Ting, Y. P., Neoh, K. G., and Kang, E. T. (2010b). Poly (1-vinylimidazole) formation on copper surfaces via surfaceinitiated graft polymerization for corrosion protection. Corros. Sci. 52, 1958-1968. doi:10.1016/j.corsci.2010.02.010

Yuan, S. J., Tang, S. W., Lv, L., Liang, B., Choong, C., and Pehkonen, S. O. (2012). Poly(4-vinylaniline)-polyaniline bilayer-modified stainless steels for the mitigation of biocorrosion by sulfate-reducing bacteria (SRB) in seawater. Ind. Eng. Chem. Res. 51, 14738-11475. doi:10.1021/ie302303x

Yuan, S. J., Xu, F. J., Kang, E. T., and Pehkonen, S. O. (2007). Modification of surface-oxidized copper alloy by coupling of viologens for inhibiting microbiologically influenced corrosion J. Electrochem. Soc. 154, C645-C657. doi:10.1149/ 1.2777013

Yuan, S. J., Xu, F. J., Pehkonen, S. O., Ting, Y. P., Kang, E. T., and Neoh, K. G. (2008). Biocorrosion behavior of titanium oxide/butoxide-coated stainless steel. J. Electrochem. Soc. 155, C196-C210. doi:10.1149/1.2885073

Zafar, S., Zafar, F., Riaz, U., and Ahmad, S. (2009). Synthesis, characterization, and anticorrosive coating properties of waterborne interpenetrating polymer network based on epoxy-acrylic-oleic acid with butylated melamine formaldehyde J. Appl. Polym. Sci. 113, 827-838. doi:10.1002/app.29726
Zuo, R., Kus, E., Mansfeld, F. B., and Wood, T. K. (2005). The importance of live biofilms in corrosion protection. Corros. Sci. 47, 279-287. doi:10.1016/j. corsci.2004.09.006

Zuo, R., Ornek, D., Syrett, B. C., Green, R. M., Hsu, C. H., Mansfeld, F. B., et al. (2004). Inhibiting mild steel corrosion from sulfate-reducing bacteria using antimicrobial-producing biofilms in Three-Mile-Island process water. Appl. Microbiol. Biot. 64, 275-283. doi:10.1007/s00253-003-1403-7

Zuo, R. G. (2007). Biofilms: strategies for metal corrosion inhibition employing microorganisms. Appl. Microbiol. Biotechnol. 76, 1245-1253. doi:10.1007/ s00253-007-1130-6

Conflict of Interest Statement: The authors declare that the research was conducted in the absence of any commercial or financial relationships that could be construed as a potential conflict of interest.

Copyright (C) 2018 Guo, Yuan, Jiang, Lv, Liang and Pehkonen. This is an open-access article distributed under the terms of the Creative Commons Attribution License (CC $B Y)$. The use, distribution or reproduction in other forums is permitted, provided the original author(s) and the copyright owner are credited and that the original publication in this journal is cited, in accordance with accepted academic practice. No use, distribution or reproduction is permitted which does not comply with these terms. 